\title{
Efektivitas Beberapa Agen Antagonis dan Cara Aplikasinya Untuk Menekan Pertumbuhan Sclerotium rolfsii pada Tanaman Kedelai (Glycine max L. Merrill)
}

\section{(The effectiveness of some agent antgonists and The Aplication to the growth of Sclerotium rolfsii at The plantssoybean (Glycine max L. Merrill)}

\author{
Nurlela ${ }^{1}$,Lukman Hakim ${ }^{1}$, M. Abduh Ulim ${ }^{1}$ \\ ${ }^{1)}$ Program Studi Agroteknologi, Fakultas Pertanian, Universitas SyiahKuala
}

\begin{abstract}
Abstrak. Penelitian ini bertujuan untuk mengetahui efektivitas beberapa agen antagonis serta cara aplikasinya dalam menekan patogen jamur $S$. rolfsii pada tanaman kedelai. Penelitian menggunakan Rancangan Acak Lengkap (RAL) Faktorial yang terdiri atas 2 faktor. Faktor pertama adalah jenis agen antagonis dan faktor kedua adalah cara aplikasi. Agen antagonis yang dicobakan yaitu Pseudomonas flourescens, Trichoderma sp., Gliocladium sp. dan Coynebacterium sp. diaplikasikan dengan perendaman kemudian diaplikasikan ke dalam tanah. Hasil penelitian menunjukkan bahwa jenis agen antagonis berpengaruh sangat nyata terhadap masa inkubasi post emergence damping-off, jenis agen antagonis berpengaruh nyata terhadap persentase perkecambahan benih kedelai, persentase benih terserang sebelum muncul ke permukaan tanah (pre emergence damping-off), dan persentase benih terserang setelah muncul ke permukaan tanah (post emergence damping-off) namun agen antagonis tidak berpengaruh nyata terhadap tinggi tanaman dan jumlah daun umur 30 hari kemudian cara aplikasi yang paling efektif adalah langsung ke dalam tanah dan tidak terdapat interaksi antara jenis agen antagonis dengan cara aplikasinya.
\end{abstract}

Kata kunci: Agen antagonis, S. rolfsii, Kedelai

\begin{abstract}
This research aims to know the effectiviveness of some antagonist agents as well ashow the application of fungal pathogens in suppressing $S$. rolfsii on soybean plants. Research using Randomized Complete Design Factorial that consists of two factors. The first factor is the type of antagonistic agents and the second factor is how the application. The antagonist agents were Pseudomonas flourescens, Trichoderma sp., Gliocladium sp. and Corynebacterium sp. were applied by soaking them to the soil. The results showed that the kind of antagonistic agent exceptionally influential real against the incubation period of post emergence damping-off, kind of antagonistic agent effect real against seed germination percentage of soybeans seeds, the percentage of stricken before surfacing to the ground (pre emergence damping-off) and the percentage of seed stricken after surfacing to the ground (post emergence damping-off) but the real antagonist agents have no effect against the high number of plants and leaves age 30 days and there is no intraction between the kind of antagonistic agent by the way of its application.

Kata kunci: antagonist agents, $S$. rolfsii, Soybean.
\end{abstract}

Keywords: Kata kunci: Antagonist agents, S. rolfsii, Soybean. 


\section{PENDAHULUAN}

Kedelai ( Glycine $\max ($ L.) Merrill) merupakan komoditas tanaman pangan yang penting dan merupakan sumber protein nabati utama bagi sebagian besar penduduk Indonesia. Bagi perekonomian Indonesia kedelai memiliki peranan yang besar karena merupakan sumber bahan baku utama bagi industri tahu, tempe dan pakan ternak. Kebutuhan kedelai dalam negeri cukup tinggi, berdasarkan angka ramalan BPS tahun 2015 produksi dalam negeri sebanyak 982.967 ton sedangkan kebutuhan kedelai sebanyak $\pm 2,2$ juta ton biji kering, kemampuan produksi dalam negeri saat ini baru mampu memenuhi sebanyak 44,68 \% terhadap kebutuhan dan sisanya sebesar 55,32 \% dipenuhi dari impor (Kusuma et al., 2016).

Salah satu kendala yang mempengaruhi produksi kedelai adalah serangan organisme pengganggu tanaman.Penyakit busuk pangkal batang atau sering disebut dengan rebah kecambah (damping-off) yang disebabkan oleh jamur Sclerotium rolfsii merupakan salah satu penyakit penting pada tanaman kedelai.Akibat serangan $S$. rolfsiipara petani kedelai sering mengalami gagal panen, walaupun pada tingkat serangan lebih dari 5\% di lapangan saja sudah dapat merugikan petani secara ekonomi (Budiman dan Tamrin, 1997).

Sudah banyak upaya pengendalian yang dilakukan untuk menekan patogen ini, seperti penggunaan fungisida, pergiliran tanaman dan penggunaan varietas tahan.Dari teknik-teknik pengendalian tersebut, yang cukup efektif dalam mengendalikan penyakit ini adalah penggunaan fungisida. Tetapi penggunaan fungisida secara terus menerus untuk mengendalikan penyakit dapat menimbulkan efek negatif seperti tercemarnya lingkungan, patogen tersebut menjadi lebih virulen dan muncul patogen-patogen sekunder akibat matinya patogen utama (Rahayu, 2008).

Teknik pengendalian biologi dengan cara memanfaatkan agen antagonis merupakan salah satu teknik pengendalian yang berpotensi untuk mengurangi dampak negatif penggunaan fungisida. Agen antagonis yang sudah banyak diuji, baik pada tingkat laboratorium maupun tingkat lapangan dan telah dimasyarakatkan ke petani saat ini adalah jamur Trichoderma sp. dan Gliocladium sp., bakteri Corynebacterium sp. dan Pseudomonas flourescens.Agen antagonis tersebut dapat dimanfaatkan untuk tujuan pengendalian penyakit tanaman yang ramah lingkungan.

Nurbailis (1992) melaporkan bahwa jamur Trichoderma sp.dan Gliocladium sp.mampu menghambat pertumbuhan jamur S. rolfsii Sacc.pada tanaman kacang tanah.Bakteri $P$. flourescens mampu menekan perkecambahan sklerotium jamur $S$. rolfsii in vitro sebesar 92\%, mampu menekan intensitas penyakit sebesar $92 \%$ dan menurunkan populasi sklerotium akhir sebesar $86,3 \%$ (Susanto et al., 2008).Corynebacterium sp. mampu menekan laju infeksi Hawar Daun Bakteri (Nurmasita et al., 2011).

Keefektifan agen antagonis dapat dipengaruhi oleh jenis agen antagonis yang diaplikasikan, juga dipengaruhi oleh cara aplikasinya. Oleh karena itu perlu dilakukan penelitian untuk mengetahui efektivitas beberapa agen antagonis yang diaplikasikan dengan cara berbeda untuk mengendalikan penyakit rebah kecambah (damping-off disease) oleh jamur S. rolfsii pada tanaman kedelai. 


\section{METODE PENELITIAN}

Penelitian ini dilaksanakan di Laboratorium Penyakit Tumbuhan dan Rumah kasa Fakultas Pertanian Universitas Syiah Kuala, Darussalam - Banda Aceh

\section{MATERI DAN METODE}

Bahan yang digunakan adalah isolat murni P. flourescens, Corynebacterium sp., Trichoderma sp. dan Gliocladiumsp. diperoleh dari Laboratorium Pengendalian Hama Penyakit Tanaman Pangan dan Hortikultura (PHPTPH) Banda Aceh, Unit Pelaksanaan Teknik Daerah - Balai Proteksi Tanaman Pangan dan Hortikultura (UPTD-BPTPH) Banda Aceh, dan isolat murni jamur S. rolfsii. berumur \pm 3 bulan, diperoleh dari Laboratorium Mikologi Departemen Penyakit Tanaman IPB, benih kedelai varietas Anjasmoro diperoleh dari Dinas Pertanian Tanaman Pangan Aceh

\section{Metode Penelitian}

Persiapan Media

Untuk membuat PDA dilakukan dengan mencampur $10 \mathrm{~g}$ bubuk PDA dalam $250 \mathrm{ml}$ aquades. Setelah tercampur, PDA disterilkan di dalam autoklafselama 30 menit bersamaan dengan cawan petri yang akan dipakai pada suhu $121^{\circ} \mathrm{C}$. Setelah selesai disterilkan, PDA dituangkan ke dalam cawan petri dan dibiarkan selama \pm 10 menit hingga PDA mengeras, selanjutnya dapat dilakukan inokulasi jamur pada media.Media NA dibuat dengan mencampurkan 5 g NA dalam $250 \mathrm{ml}$ aquades kedalam erlenmeyer. Lalu diaduk hingga larutan homogen dengan menggunakan stirrer magnetik, kemudian disesuaikan $\mathrm{pH}$ menjadi 7 dengan menambahkan larutan $\mathrm{NaOH}$ dan disterilkan di dalam autoklaf selama 30 menit pada suhu $121^{\circ} \mathrm{C}$. Setelah selesai di sterilkan, NA dituang ke dalam cawan petri dan dibiarkan selama 10 menit hingga NA mengeras.

Peremajaan Isolat

Biakan S. rolfsii., Trichoderma sp. dan Gliocladium sp diremajakan di cawan petri, dengan menggunakan media PDA, selanjutnya diinkubasikan pada kondisi suhu ruangan $\left(25-29^{\circ} \mathrm{C}\right)$ selama 7 hari, untuk S. rolfsii dibiarkan pada kondisi suhu ruangan selama 4 minggu, Sedangkan $P$. flourescens dan Corynebacterium sp. diremajakan di cawan petri dengan menggunakan media NA, selanjutnya diinkubasi dalam inkubator pada suhu $29-31^{\circ} \mathrm{C}$ selama 24 jam (Hasanuddin, 2003).

Perbanyakan Patogen S. rolfsii.

Biakan $S$. rolfsii yang telah diremajakan di cawan Petri selama 4 minggu diperbanyak kembali pada media sekam. Media sekam ini dibuat dari campuran sekam sebanyak $30 \mathrm{~g}$ dan air sebanyak $30 \mathrm{ml}$ yang dimasukkan ke dalam kantong plastik tahan panas untuk kemudian disterilisasi menggunakan autoklaf pada suhu $121^{\circ} \mathrm{C}$ selama 30 menit. Setiap media sekam tersebut diberikan isolat $\mathrm{S}$. rolfsii sebanyak $1 / 4$ bagian medium PDA dari hasil perbanyakan. Isolat $S$. rolfsii pada media sekam selanjutnya dibiarkan selama 4 minggu pada suhu ruang sebelum diinokulasikan ke media tanam (Yulianti dan Suhara, 2010).

Persiapan Media Tanam 
Media tanam yang digunakan untuk penelitian ini adalah media campuran tanah top soil dan dicampur pupuk kandang, sebelum dimasukkan ke dalam polybag tanah diayak terlebih dahulu untuk membersihkan tanah dari biji-biji gulma yang mungkin terbawa dan supaya tekstur tanah menjadi halus.Setelah diayak tanah dicampur pupuk kandang dengan perbandingan (2:1) kemudian diaduk sampai merata lalu dimasukkan ke dalam plastik tahan panas untuk disterilkan di dalam autoklafselama 30 menit dengan suhu $121^{\circ}$ C.Selesai disterilisasi, tanah dimasukkan ke dalam polybag sebanyak $5 \mathrm{~kg} /$ polybag. Tanah yang digunakan adalah tanah Alluvial yang diperoleh dari pinggiran sungai Indrapuri Kecamatan Aceh Besar.

Inokulasi $S$. rolfsii pada Media Tanam

Media sekam yang telah ditumbuhi $S$. rolfsii ditaburkan ke dalam masing-masing polybag sebanyak $15 \mathrm{~g} /$ polybag, kemudian tanah dan $S$. rolfsii yang ada di dalam polybag diaduk sampai homogen. $S$. rolfsii diinokulasikan pada saat seminggu sebelum melakukan penanaman.

Aplikasi Agen Antagonis

Aplikasi agen antagonis dilakukan seminggu setelah inokulasi S. rolfsii. Sesuai dengan perlakuan yang dicobakan, pada perlakuan perendaman benih, benih direndam dengan agen antagonis $P$. flourescens, Trichoderma sp., Gliocladium sp. dan Corynebacterium sp. selama 15 menit dengan tingkat pengenceran $10^{-6}$ (Pengenceran dilakukan dengan mengambil masing-masing $1 \mathrm{ml}$ suspensi kemudian ditambah dengan $9 \mathrm{ml}$ air steril), lalu benih kedelai ditanam pada media tanam yang telah disediakan. Menurut penelitian yang dilakukan oleh Nasikhah (2008), yaitu konsentrasi yang mempengaruhi $P$. flourescens dalam menghambat perkembangan $S$. rolfsii pada konsentrasi $10^{-6} \mathrm{cfu} / \mathrm{ml}$. Untuk perlakuan pemberian ke dalam tanah agen antagonis $P$. flourescens., Trichoderma sp., Gliocladium sp. dan Corynebacterium sp. menggunakan tingkat pengenceran $10^{-6}$. Menggunakan pengenceran yang sama dengan perlakuan perendaman benih, dengan volume aplikasi $50 \mathrm{ml} /$ polybag (Nasikhah, 2008).

Penanaman

Pada setiap polybag disiapkan 10 lubang tanam.Benih kedelai ditanam sebanyak 1biji/lubang, kemudian lubang tanam ditutup.Penanaman dilakukan seminggu setelah aplikasi $S$. rolfsii.

\section{Analisa Statistik}

Rancangan yang digunakan pada penelitian ini adalah Rancangan Acak Lengkap (RAL).Apabila terdapat perbedaan yang nyata maka dilakukan uji lanjut Beda Nyata Terkecil (BNT) pada taraf 5\%.

\section{Parameter yang Diamati}

1. Persentase Perkecambahan Benih Kedelai

Persentase perkecambahan dihitung 2 minggu setelah aplikasi $S$. rolfsii atau 7 hari setelah tanam (HST).Persentase dihitung dari jumlah kecambah yang tumbuh dibagi jumlah seluruh kecambah yang ditanam (Suryanto et al., 2010). Perhitungan persentase perkecambahan benih menggunakan rumus sebagai berikut:

$$
\mathrm{P}=\frac{a}{b} \times 100 \%
$$

Keterangan: 
$\mathrm{P}=$ persentase perkecambahan

$\mathrm{a}=$ benih yang tumbuh

$\mathrm{b}=$ jumlah benih yang ditanam

Pengamatan persentase perkecambahan dilakukan dengan menggunakan metode pengamatan Suryanto et al., 2010 yaitu dihitung pada 7 HST.

2. Masa Inkubasi S. rolfsiiPost Emergence Damping Off

Masa inkubasi diamati mulai dariwaktu aplikasi jamur sampai timbulnya gejala awal yang ditandai dengan busuknya batang, kekuningan dan kelayuan pada cabang kedelai.

3. Persentase Bibit Terserang Sebelum Muncul ke Permukaan Tanah (Pre Emergence Damping Off)

Pengamatan persentase bibit terserang sebelum muncul ke permukaan tanah dilakukan setiap hari sampai hari ke tujuh, dimana tidak ada benih yang muncul lagi.Pengamatan yang dilakukan menggunakan metode pengamatan Fuadi (2010). Persentase bibit terserang dapat dihitung dengan rumus :

$\mathrm{S}=\frac{\mathrm{A}-\mathrm{B}}{\mathrm{B}} \times 100 \%-(100 \%-\mathrm{D})$

Daya kecambah benih dihitung dengan menggunakan rumus :

$\mathrm{D}(\%)=\frac{\sum \mathrm{KN} \text { pengamatan } \mathrm{I}+\sum \mathrm{KN} \text { pengamatan II }}{\text { Jumlah benih yang ditanam }} \times 100 \%$

Keterangan :

$\mathrm{S} \quad=$ Persentase bibit terserang sebelum muncul ke permukaan tanah (\%)

A = Jumlah benih disemaikan

$\mathrm{B} \quad=$ Jumlah tanaman yang muncul

$\mathrm{D} \quad=$ Daya kecambah benih $(\%)$

$\mathrm{KN}=$ Kecambah Normal

4. Persentase Bibit Terserang Setelah Muncul ke Permukaan Tanah (Post Emergence Damping Off)

Persentase tanaman berkecambah yang terserang setelah muncul ke permukaan tanah dihitung berdasarkan jumlah bibit yang terserang setiap hari.Pengamatan dilakukan sejak muncul gejala serangan pertama sampai tanaman berumur 14 HST.Pengamatan yang dilakukan menggunakan metode pengamatan Fuadi (2010). Data pengamatan dihitung dengan menggunakan rumus :

$\mathrm{K}=\frac{n}{N} \times 100 \%$

Keterangan:

$\mathrm{K}=$ Persentase bibit terserang setelah muncul ke permukaan tanah $(\%)$

$\mathrm{n} \quad=$ Jumlah bibit terserang

$\mathrm{N}=$ Jumlah bibit tumbuh 


\section{HASIL DAN PEMBAHASAN}

\section{Persentase Perkecambahan Benih Kedelai}

Tabel 2.Rata-rata Persentase Perkecambahan Benih Kedelai pada Umur 7 HST Akibat Perlakuan Beberapa Agen Antagonis dan Cara Aplikasinya untuk Menekan Pertumbuhan Jamur S. rolfsii.

\begin{tabular}{ll}
\hline Perlakuan & Perkecambahan Benih Kedelai \\
\hline Agen Antagonis & \\
PF & 68,33 \\
T & $48,33 \mathrm{a}$ \\
G & $50,00 \mathrm{ab}$ \\
C & $52,86 \mathrm{ab}$ \\
BNT & 19,11 \\
Cara Aplikasi & \\
A1 & 54,17 \\
A2 & 60,00 \\
\hline KK & 22,33 \\
\hline
\end{tabular}

Keterangan : Angka yang diikuti oleh huruf yang sama tidak berbeda nyata pada taraf 0,05 (Uji BNT).

Berdasarkan Tabel 2 dapat dilihat bahwa persentase perkecambahan benih tertinggi terdapat pada pemberian agen antagonis $P$. flourescens dengan rata-rata $68,33 \%$ tidak berbeda nyata terhadap agen antagonis Gliocladium sp. dengan ratarata persentase perkecambahan benih $50,00 \%$ dan Corynebacterium sp. dengan rata-rata 52,86\%, tetapi berbeda nyata terhadap Trichoderma sp. dengan rata-rata 48,33\%.Tingginya persentase perkecambahan benih pada pemberian agen antagonis $P$. flourescens disebabkan karena agen antagonis tersebut dapat menghambat pertumbuhan $S$. rolfsii.yang terdapat di dalam tanah. Disamping berfungsi sebagai agen antagonis, $P$. flourescensjuga dapat berfungsi sebagai pemacu pertumbuhan dan pengurai bahan organik bagi tanaman.Pada berbagai eksperimen, agen antagonis $P$. flourescens dapat memperbaiki kesehatan dan vigor tanaman dan meningkatkan pertumbuhan perakaran (Lestari et al., 2007).

Bakteri $P$. flourescensmenghasilkan fitohormon khususnya IAA (Indole Asetic Acid) dan ACC (Aminocyclopropne Carboxylic Acid) deaminase.IAA yaitu salah satu jenis hormon yang dapat memacu perkecambahan dan pertumbuhan tanaman dengan meningkatkan laju pertumbuhan akar, seperti pemanjangan akar primer serta perbanyakan akar lateral dan akar adventif, yang merupakan suatu keuntungan bagi kecambah dalam meningkatkan kemampuannya untuk lebih merekatkan diri ke tanah, menyerap air serta nutrisi dari lingkungan sehingga tanaman tersebut dapat bertahan (Wanjiru, 2009). Umumnya tanaman tidak mampu menghasilkan IAA dalam jumlah cukup untuk pertumbuhan dan perkembangannya.P. flourescens mampu mensintesis IAA yang terdapat dalam eksudat akar maupun dari bahan organik.Senyawa aktif ini dapat meningkatkan maupun menghambat pertumbuhan tanaman tergantung konsentrasinya (Aryantha, 2004).

P. flourescensyang hidup di daerah perakaran tanaman dapat berperan sebagai jasad renik pelarut fosfat, mengikat nitrogen dan menghasilkan zat 
pengatur tumbuh bagi tanaman, dengan kemampuan tersebut $P$. flourescens dapat dimanfaatkan sebagai pupuk biologis yang dapat menyediakan hara untuk pertumbuhan tanaman (Kartika, 2012).Mekanisme pelarutan fosfat oleh bakteri pelarut fosfat diawali dari sekresi asam-asam organik diantaranya asam formiat, asetat, propionat, laktat, glikolat, glioksilat, fumarat, tartat, ketobutirat, suksinat dan sitrat, dengan meningkatnya asam-asam organik tersebut akan diikuti dengan penurunan nilai $\mathrm{pH}$ sehingga mengakibatkan terjadinya pelarutan $\mathrm{P}$ yang terikat oleh Ca (Rohmah, 2011).

Masa Inkubasi S. rolfsii Post Emergence Damping off

Tabel 3. Rata-rata Masa Inkubasi S. rolfsiiPost Emergence Damping off Akibat Perlakuan Beberapa Agen Antagonis dan Cara Aplikasinya untuk Menekan Pertumbuhan Jamur S. rolfsii pada Tanaman Kedelai

\begin{tabular}{ll}
\hline Perlakuan & Masa Inkubasi \\
\hline Agen Antagonis & $14,21 \mathrm{~b}$ \\
PF & $12,80 \mathrm{a}$ \\
T & $15,30 \mathrm{c}$ \\
G & $12,85 \mathrm{a}$ \\
C & 1,89 \\
BNT & \\
Cara Aplikasi & 12,11 \\
A1 & 11,70 \\
A2 & 10,57 \\
\hline KK &
\end{tabular}

Keterangan: Angka yang diikuti oleh huruf yang sama tidak berbeda nyata pada taraf 0,05 (Uji BNT).

Berdasarkan Tabel 3 dapat dilihat bahwa, masa inkubasi terlama dijumpai melalui pemberian agen antagonis Gliocladium sp. yaitu 15,30 hari. Hal ini diduga karena Gliocladium sp. dapat memainkan peran mekanisme antagonisnya dengan lebih efektif.Mekanisme tersebut dapat berupa antibiosis,lysis, persaingan dan parasitisme (Lewis danPapavizas, 1984) dengan kemampuan tumbuh yang lebih cepat dibandingkan $S$. rolfsii maka Gliocladium sp. tersebut cepat menguasai ruang tumbuh dan nutrisi, Gliocladium sp. yang diberikan mengakibatkan masa inkubasi menjadi lebih lambat.Pemberian agen antagonis dapat mengurangi kepadatan inokulum penyebab penyakit, aktifitas patogen atau parasit dalam keadaan aktif atau dorman sehingga mencegah terjadinya penyakit tanaman (Cook dan Baker, 1996).

MenurutPapavizas (1985) bahwa Gliocladium sp. memproduksigliotoksin dan viridin.Gliotoksin dapat menghambat cendawan dan bakteri, sedangkan viridin dapat menghambat cendawan (Winarsih, 2007).Mehrotra (1980) menyatakan bahwa konidia Gliocladium sp.berkecambah di sekitar perakaran tanaman.Laju pertumbuhan Gliocladium sp. menjadi cepat akibat adanya rangsangan dari jamur patogen.Gliocladium sp. yang bersifat mikoparasit akan menekan populasi jamur patogen yang sebelumnya menguasai. 


\section{Persentase Benih Terserang Sebelum Muncul ke Permukaan Tanah (Pre Emergence Damping off)}

Tabel 4. Rata-rata Persentase Benih Terserang Sebelum Muncul ke Permukaan Tanah (Pre Emergence Damping off) Akibat Perlakuan Beberapa Agen Antagonis dan Cara Aplikasinya untuk Menekan Pertumbuhan Jamur $S$. rolfsii pada Tanaman Kedelai

\begin{tabular}{ll}
\hline Perlakuan & Pre emergence $(\%)$ \\
\hline Agen Antagonis & \\
PF & $20,38 \mathrm{a}$ \\
T & $67,50 \mathrm{c}$ \\
G & $57,14 \mathrm{bc}$ \\
C & $25,95 \mathrm{ab}$ \\
BNT & 35,68 \\
Cara Aplikasi & \\
A1 & 49,50 \\
A2 & 35,99 \\
\hline KK & 55,69 \\
\hline Keterangan
\end{tabular}

Keterangan: Angka yang diikuti oleh huruf yang sama tidak berbeda nyata pada taraf 0,05 (Uji BNT).

Berdasarkan Tabel 4 dapat dilihat bahwa pemberian agen antagonis $P$. flourescens dan Corynebacterium sp. memberikan hasil yang berbeda nyata jika dibandingkan dengan agen antagonis Trichoderma sp. dimana persentase serangan pada benih sebelum muncul ke permukaan tanah yang paling rendah adalah pada pemberian agen antagonis $P$. flourescens yaitu $20,38 \%$, sedangkan persentase tertinggi terdapat pada pemberian agen antagonis Trichoderma sp. yaitu 67,50\%.

Pemberian agen antagonis $P$. flourescens menunjukkan hasil yang dapat menekan perkembangan dan infeksi patogen $S$. rolfsii pada benih. Hal ini disebabkan karena mekanisme antagonis $P$. flourescens tersebut berjalan dengan baik dalam menghambat jamur patogen $S$. rolfsii.P. flourescens dapat menekan populasi patogen dengan melindungi akar dari infeksi patogen tular tanah dengan cara mengkolonisasi permukaan akar, menghasilkan senyawa kimia seperti anti jamur dan antibiotik, serta kompetisi dalam penyerapan kation Fe (Machmud et al., 2002). Hal inisesuai penelitian Widodo (1993), bahwa patogen sulit melakukanpenetrasi apabila sistem perakaran terdominasi olehantagonis.Baharuddin et al., (2005) berhasil memanfaatkan Pseudomonas kelompok flourescens untuk menekan intensitas layu bakteri cabai.

Lam dan Gaffney (1993) menyatakan bahwa kemampuan P. flourescens sebagai agensia pengendalian hayati berkaitan dengankemampuannya bersaing untuk mendapatkan zat makanan atau karenamenghasilkan senyawa-senyawa metabolit seperti siderofor, antibiotik atau enzimekstraselluler. Senyawa tersebut bersifat antagonis yaitu menghambat atauberkompetisi dengan patogen tular tanah di sekitarnya. Schipper (1987) menambahkan, mekanisme penghambatan $P$. flourescens terhadap organisme lain meliputi produksi senyawa anti fungi, kompetisi senyawa Fe, kompetisi tempat dan nutrisi. Perlakuan bakteri antagonis seperti Pseudomonas sp. dapat memberikan sistem pertahanan (bioprotektan), 
karena bakteri ini dapat mengeluarkan senyawa antibiosis yang mampu memberikan sinyal terhadap tanaman yang terserang agar melakukan pertahanan diri (Jatnika et al., 2013). Pengendalian penyakit secara langsung dilakukan dengan cara bakteri antagonis memproduksi antibiotik yang dapat menghambat pertumbuhan patogen.

\section{Persentase Benih Terserang Setelah Muncul ke Permukaan Tanah (Post Emergence Damping off)}

Tabel 5. Rata-rata Persentase Benih Terserang Setelah Muncul ke Permukaan Tanah (Post Emergence Damping off) Akibat Perlakuan Beberapa Agen Antagonis dan Cara Aplikasinya Untuk Menekan Pertumbuhan Jamur S. rolfsii pada Tanaman Kedelai

\begin{tabular}{ll}
\hline Perlakuan & Post emergence (\%) \\
\hline Agen Antagonis & \\
PF & $29,51 \mathrm{a}$ \\
T & $51,31 \mathrm{~b}$ \\
G & $21,67 \mathrm{a}$ \\
C & $38,57 \mathrm{ab}$ \\
BNT & 21,16 \\
Cara Aplikasi & \\
A1 & $40,91 \mathrm{a}$ \\
A2 & $28,63 \mathrm{a}$ \\
\hline KK & 40,03 \\
\hline
\end{tabular}

Keterangan:Angka yang diikuti oleh huruf yang sama tidak berbeda nyata pada taraf 0,05 (Uji BNT)

Berdasarkan data Tabel 5 dapat dilihat bahwa persentase benih terserang setelah muncul ke permukaan tanah (Post emergence damping off) yang terendah dijumpai pada jenis agen antagonis Gliocladium sp. dengan rata-rata 21,67\%, sedangkan persentase tertinggi dijumpai pada jenis agen antagonis Trichoderma sp. dengan rata-rata 51,31\% . Berdasarkan hal tersebut terlihat bahwa Gliocladium sp. dapat menekan tingkat serangan jamur $S$. rolfsii.setelah tanaman muncul ke permukaan tanah. Dengan adanya pemberian agen antagonis Gliocladium sp. akan menurunkan tingkat kevirulenan jamur $S$. rolfsii melalui mekanisme antagonis yang dimiliki agen antagonis tersebut. Menurut Highley (1995) bahwa Gliocladium virens memproduksi sejumlah agen anti jamur seperti Gliovirin dan Gliotoksin, juga kompetisi dan parasitisme merupakan mekanisme antagonis yang utama dengan miselium yang efektif.Gliocladium sp. juga dapat menghambat penyebab penyakit lainnya seperti Rhizoctonia spp., Pythium spp. dan penyebab penyakit akar (College, 2009).Hasil penelitian Winarsih (2007) Gliocladium sp. mampu menekan $S$. rolfsii sampai $85 \%$ secara in vitro.

Rata-rata persentase benih terserang setelah muncul ke permukaan tanah (Post emergence damping off) terendah terdapat pada cara aplikasi pemberian kedalam tanah dengan rata-rata 28,63\%. Hal ini disebabkan karena agen antagonis yang diberikan kedalam tanah telah berkembangbiak secara optimal sehingga dapat menekan pertumbuhan jamur $S$. rolfsii.akibatnya persentase serangan lebih 
rendah. Hal ini sesuai dengan hasil penelitian yang dilakukan Kurrata (2007), cara aplikasi $P$. flourescens melalui tanah dengan konsentrasi $10^{9} \mathrm{cfu} / \mathrm{ml}$ merupakan cara aplikasi dan konsentrasi terbaik dalam menekan penyakit rebah semai $S$. rolfsii.

Cara aplikasi mempengaruhi jumlah dan daya antagonis, semakin efektif cara pengaplikasiannya maka semakin besar pula jumlah serta daya antagonisnya. Cara aplikasi perendaman benih memiliki persentase serangan lebih tinggi dibandingkan dengan cara aplikasi ke dalam tanah. Hal ini diduga karena waktu perendaman benih terlalu singkat sehingga tidak seluruh benih dapat menyerap agen antagonis, jumlah agen antagonis yang diserap hanya sedikit sehingga agen antagonis tersebut tidak keseluruhan dapat melindungi benih dari serangan jamur $S$. rolfsii.Dari hasil pengamatan tersebut menunjukkan bahwa perkembangan penyakit sangat ditentukan oleh jumlah agen antagonis di dalam tanah. Semakin besar jumlah agen antagonis dalam tanah maka aktivitas antagonis terhadap jamur patogen semakin tinggi. Hal ini sesuai dengan hasil penelitian yang dilakukan Alfizar et., al (2011) menunjukkan bahwa semakin tinggi jumlah agen antagonis, akan semakin menekan patogen, akibatnya kemampuan patogen yang berkembang semakin sempit sehingga persentase tanaman terserang semaikin rendah. Agen antagonis yang diberikan kedalam tanah jumlahnya lebih banyak sehingga mempunyai kesempatan lebih besar untuk berkembang kemudian dapat membantu tanaman dalam menyerap unsur hara sehingga tanaman mempunyai ketahanan tubuh yang lebih kuat.

\section{KESIMPULAN DAN SARAN}

$P$. flourescens paling efektif dalam mempengaruhi persentase perkecambahan benih dan menekan persentase benih terserang sebelum muncul ke permukaan tanah sedangkan Gliocladium sp. sangat efektif dalam memperpanjang masa inkubasi post emergence damping off dan menekan persentase benih terserang setelah muncul ke permukaan tanah.

Aplikasi agen antagonis langsung ke dalam tanah paling efektif menekan persentase benih terserang setelah muncul ke permukaan tanah.

Tidak terdapat interaksi antara jenis agen antagonis dan cara aplikasinya terhadap persentase perkecambahan benih kedelai, masa inkubasi $S$. rolfsiipost emergence damping off, persentase benih terserang sebelum muncul ke permukaan tanah (pre emergence damping off), persentase benih terserang setelah muncul ke permukaan tanah (post emergence damping off), tinggi tanaman dan jumlah daun kedelai.

\section{DAFTAR PUSTAKA}

Alfizar, Marlina \& N. Hasanah. 2011. Upaya Pengendalian Penyakit Layu Fusarium oxysporum Dengan Pemanfaatan Agen Hayati Cendawan FMA dan Trichoderma harzianum. J. Floratek. Fakultas Pertanian Universitas Syiah Kuala Banda Aceh. Banda Aceh. 
Aryantha. 2004. Potensi Isolat Bakteri Penghasil IAA dalam Peningkatan Pertumbuhan Kecambah Kacang Hijau pada Kondisi Hidroponik. Jurnal Mikrobiologi Indonesia. 9(2): 43-46.

Baharuddin, Nursaba \& T. Kuswinanti. 2005. Pengaruh pemberian Pseudomonas fluorescens "effective microorganism 4" dalam menekan penyakit layu bakteri (Ralstonia solanacearum) pada tanaman cabai. Prosiding Seminar Ilmiah dan Pertemuan Tahunan PEI dan PFI XVI Komda Sul-Sel. 2005 Nov 22; Makasar.PEI dan PFI Komda Sul-Sel. hlm 195-200.

Budiman, A. \& M. Thamrin. 1997. Keefektifan 11 Fungisida Terhadap Penyakit Sclerotium rolfsii Sacc. Pada Tanaman Kedelai di Lahan Kering.Banjar baru: Balai Penelitian dan Pengembangan Pertanian dan Balai Penelitian Tanaman Pangan. Banjar baru.

College. W. 2009. Gliocladium. Virens. http:www.entomology.wisc. edu/mbcn/kvf 509.html. [10 Maret 2016]

Cook, R.J. \& K.F. Baker. 1996. The Nature And Practice Of Biological ControlOf Plant Patogens.Minnesota: APS Press.

Fuadi I. 2010. Pengendalian Hayati Penyakit Layu (Fusarium oxysporumSchlecht) pada Tanaman Caisin (Brassica Campestris var. Chinensis). Tesis. Program Pasca Sarjana Universitas Islam Riau. Pekan Baru.

Hasanuddin, 2003.Peningkatan Peranan Mikroorganisme Dalam Sistem Pengendalian Penyakit Tumbuhan Secara Terpadu. Jurusan Hama Dan Penyakit Tumbuhan Fakultas Pertanian Universitas Sumatera Utara, http://library.usu.ac.id/download/fp/fp-hasanuddin.pdf. Diakses tanggal $\underline{21 \text { April } 2015}$

Highley, T.L. 1995. Control of wood decay by Trichoderma (Gliocladium) virens, I Antagonistic Properties.Forest Product laboratory, Madison. WI. USA.

Jatnika, W., A. L. Abadi \& L. Q. Aini.2013. Pengaruh Aplikasi Bacillus sp. dan Pseudomonas sp. Terhadap Perkembangan Penyakit Bulai yang Disebabkan Oleh Jamur Patogen Peronoslerospora maydis Pada Tanaman Jagung. Jurnal HPT 1(3) :19-29

Kartika, A. B. 2012.Teknik Eksplorasi \& Pengembangan BakteriPseudomonas.flourescens..www.laboratoriumphpbanyumas.com/i siwebsite/AGENSIA HAYATI/eksplorasi Pseudomonas flourescens.pdf. [Diakes tanggal 11 maret 2016]

Kurrata, G. 2007. Pengaruh Isolat Bakteri Antagonis Pseudomonas fluorescens Terhadap Sclerotium rolfsii sacc.Skripsi. Malang: Jurusan Hama danPenyakit Tumbuhan, Universitas Brawijaya. 
Kusuma, R., N. Sa'dyiah \& Y. Nurmiati.2016. Keragaman Fenotipe dan Heritabilitas Kedelai (Glycine $\max$ [L.] Merril) Generasi $\mathrm{F}_{6}$ Hasil Persilangan Wilis X Mlg 2521

Lam, S. T., \& T. D. Gaffney. 1993. Biological activities of bacteria used in plant pathogen control. Pages 291-320 In: Biotecnology in Plant Disease Control. I. Chet, ed. Wiley-Liss, New York.

Lestari, P., D. N. Susilowati \& E.I. Riyanti, 2007.Pengaruh Hormon Asam Indol Asetat yang Dihasilkan oleh Azospirillum sp. Terhadap Perkembangan Akar Padi.Jurnal Agro Biogen. 3(2): 66-71.

Lewis, J. A \& G. C. Papavizas, 1984. Characteristic of alginate pellets formulated with Trichoderma and Gliocladium and their effect on the proliferation of the fungi in soil. Plant Pathology 34:571-575

Manik, C.A. 2011. Uji Efektivitas Corynebacterium dan Dosis Pupuk K terhadap Serangan Penyakit Kresek (Xanthomonas campestris pv oryzae) Pada Padi Sawah (Oriza sativa L) di Lapangan. www.repository.usu.ac.id. [Diakses 27 April 2016]

Mehrotra, R.S. 1980. Plant pathology. Tata McGraw Hill Publishing Co. Ltd. New Delhi.

Nasikhah, K. 2008. pengaruh isolat alami Pseudomonas fluorescens pada beberapa tingkat pengenceranterhadap jamur sclerotium rolfsii penyebab penyakit layu pada kedelai (Glycine max (L) merill). Skripsi. Fakultas sains dan teknologi Universitas Islam Negeri Malang.

Nurbailis. 1992. Pengendalian hayati Sclerotium rolfsii Sacc. penyebab busuk batangkacang tanah (Arachis hipogaea L.)dengan kompos dan cendawanantagonis. Tesis. Pascasarjana Institut Pertanian Bogor. Bogor. 58 hal.

Nurmasita, L., Luice, A. Taulu \& Bahtiar. 2011. Potensi Corynebacterium sebagai pengendali penyakit hawar daun bakteri pada tanaman padi. Balai Pengkajian Teknologi Pertanian. Manado.

Papavizas, G. C. 1985. Trichoderma sp. and Gliocladium sp. Biology, Biecology and Potential for Biocontrol.Ann. Rev. Phytopathology 23: 23-50.

Rahayu, M. 2008. Efikasi Isolat Pseudomonas fluorescens terhadap Penyakit Rebah Semai pada Kedelai. Penelitian Pertanian Tanaman Pangan. 27(8): 179-184. 
Rohmah, F. 2011. Pemanfaatan Bakteri Pseudomonas fluorescens, JamurTrichoderma harzianum dan Seresah Daun Jati (Tectona grandis) untuk Pertumbuhan Tanaman Kedelai pada Media Tanam Tanah Kapur.Rao NSS.Mikroorganisme Tanah dan Pertumbuhan Tanaman. Jakarta: UI-Press.

Schipper, B., A. W. Baker, D. A. H. M and Scher. 1987. Interactions of Deletirous and Benefical Rhizosphere Microorganism and the Effect of Cropping Practices. Ann. Rev. Phytopathol.

Wanjiru, M. 2009. Effect of Trichoderma HarzianumAndArbuscular Mycorrhizal fungi on Growth of Tea Cuttings, Napier Grass and Disease Management in Tomato Seedling. Plant and Microbial Sciences. 13, 305-312.

Widodo.1993. Penggunaan Pseudomonas kelompok Flourescens untuk mengendalikan penyakit akar gada pada tanaman caisin (Brassica campestris var. Chinensis) Tesis.IPB Bogor.

Winarsih, S. 2007. Pengaruh bahan organik pada pertumbuhan Gliocladium virens dan daya antagonisnya terhadap Fusarium oxysporum secara invitro.Jurnal Ilmu-ilmu Pertanian Indonesia. Edisi Khusus (3):386-390.

Winarsih, S. 2007. Pengaruh bahan organik pada pertumbuhan Gliocladium virens dan daya antagonisnya terhadap Fusarium oxysporum secara invitro.Jurnal Ilmu-ilmu Pertanian Indonesia. Edisi Khusus (3):386-390.

Yulianti, T \& C. Suhara. 2010. Patogenitas Sclerotium rolfsii, Rhizoctonia solani dan $R$. bataticola dari Beberapa Sumber Inokulum Terhadap Kecambahan Wijen (sesenum $\backslash$ indicum L.) http://balittas.litbang.deptan.go.id/ind/images/wijen07/patogenitas.pdf [Diakses tanggal 25 oktober 2015] 
